\title{
Multimodal transport: the case of Laotian garment exporters

\section{Ruth Banomyong}

Faculty of Commerce and Accountancy, Thammasat University, Thailand, and Anthony K.C. Beresford

\author{
Cardiff Business School, Cardiff University, UK
}

Keywords Developing countries, Transport operations, Modelling, Export, Lao

\begin{abstract}
This paper explores the various alternative routes and methods available to garment exporters in Lao PDR, a land-locked country in South East Asia, when exporting to the European Union. Lao exporters are dependent on the transport systems in place in neighbouring countries (i.e. Vietnam, Thailand, Malaysia and Singapore) for transit purposes. A multimodal transport cost-model is used to illustrate and clarify multimodal transport routeing alternatives. A confidence index is also introduced for each route, transport modes and nodal links. Five routeing alternatives are presented in this paper and it is shown that the most frequently utilised route via Bangkok (Thailand) is not necessarily the most competitive in terms of time and cost, while the route via Port Klang (Malaysia) potentially offers a better alternative for Lao garment exporters.
\end{abstract}

\section{Introduction}

The purpose of this paper is to present a cost model of multimodal transport, which was originally proposed by Boerne (1990) and developed by Beresford and Dubey (1990). The model is stand-alone and flexible enough to be applied to any operational circumstances and to a supply chain of any length. The validity of this model is tested against a real case in international supply chain movement, namely the export of garments from Lao People's Democratic Republic (PDR) to the port of Rotterdam in The Netherlands, one of the main European entry points.

The main elements of the model are as follows: cost, time, distance, transport mode and intermodal transfer. The model is tested using real data over a series of alternative routes between Lao PDR and Rotterdam. The data were obtained from Laotian garment exporters, transport service providers and shipping lines. The model may also be used as a part of the process in transport policy formulation.

Lao PDR is the sole land-locked country in Southeast Asia and is taken in this paper as an illustrative case study. The country is surrounded by five states: the Peoples Republic of China, the Socialist Republic of Vietnam, The Kingdom of Cambodia, the Kingdom of Thailand and the Union of Myanmar. Adequate transport and communications facilities play a vital role in the country's economic development and an efficient multimodal transport system can be one of the key factors in increasing Lao PDR's trade competitiveness.

Tougher international competition and expansion of geographical markets have forced manufacturers and exporters to focus on integrated production and

International Journal of Physical Distribution \& Logistics Management, Vol. 31 No. 9, 2001, pp. 663-685. (C) MCB University Press, 0960-0035 
IJPDLM

31,9

664 transport logistics strategies in order to reduce costs, and at the same time, to obtain a higher service standard. The need to control the transport costs has become as important as the need to keep down other production costs. The emergence of reliable and competitive door-to-door multimodal transport services can contribute to, and foster, new trading opportunities as well as increased competitiveness (UNCTAD, 1994).

The competitiveness of internationally traded products is greatly influenced by various factors, which build up the overall transportation cost. The cost associated with the physical transfer of the goods is an essential piece of information in the negotiation of an international trade transaction (Carter and Ferrin, 1995; Bertazzi et al., 1997). Transit time is also an important element as goods in transit cost money (Allen et al., 1985; Blummenfeld et al., 1985; Tyworth and Zeng, 1998). Uncertainty in cost quantifying (direct as well as indirect) is another issue faced by traders that might disadvantage an exporter (ESCAP, 1997). The above-mentioned considerations indicate that trading opportunities can benefit from better-organised transport services such as integrated multimodal transport.

\section{International transit}

International transit transport in the Greater Mekong Sub-region (GMS)[1] has been the subject of much discussion in recent years with Bezy (1996) highlighting the areas where effort has been focused. Field missions to Singapore, Malaysia, Thailand, Lao PDR and Vietnam in 1994, to Cambodia in 1995 and to Myanmar in 1996 have shown that:

- There is an insufficient use of key waterways.

- There is a need to encourage and promote freight forwarding, the development of multimodal transport and integrated transport logistics.

- There is a need to promote the development and expansion of the Inland Clearance Depot (ICD) concept.

- Documentation, customs procedures and data exchange need to be simplified and harmonised.

- Greater use of rail transport (partly through the ICD concept) should be encouraged.

- Better cross-border co-operation and transport co-ordination is needed.

- The use of combined transport or multimodal transport document should be expanded.

- ASYCUDA (Automatic System for Customs Data) and EDI (Electronic Data Interchange) should be adopted as widely as possible, bringing time, security and cost benefits.

Another development taking shape is the formulation of an ASEAN[2] (Association of South East Asian Nation) customs transit system for the 
facilitation of goods in transit, which will form part of the ASEAN Framework Agreement on the Facilitation of Goods in Transit. This is a co-ordinated effort among ASEAN bodies covering customs, trade and transport. Another ASEAN Framework Agreement on Multimodal Transport is currently being negotiated. According to Banomyong (1999), these agreements are expected to contribute further to the facilitation of goods transported within ASEAN, particularly among the countries in mainland South East Asia.

\section{Methodology}

The choice of transport mode or combination of transport modes has a direct impact on the efficiency of a multimodal transport system. Depending on the mode chosen (Liberatore and Miller, 1995), the overall performance of the multimodal transport system will be affected. Simple cost-distance models of road versus rail are commonly found (Fowkes et al., 1989; Hayuth, 1992; Marlow and Boerne, 1992) for national movements or sea versus air (Hayuth, 1986; Jung, 1994) over longer, intercontinental routes. As the multimodal choice is of vital importance to the success of international trade, various models have also been created (Beresford and Dubey, 1990; Beresford, 1999; Minh, 1991; Barnhart and Ratliff, 1993; Yan et al., 1995) to aid transport decision makers in choosing the most effective transport mode or combination of transport modes that not only minimises cost and risk, but also satisfies various on-time service requirements.

The cost model, which is presented here, includes both transport (road, rail, inland waterway, sea) and intermodal transfer (ports, railfreight terminals, inland clearance depots) as cost components. This model has been adapted from Beresford and Dubey (1990) and improved by Beresford in 1999. The model may be considered in four developmental stages from its basic form (Figure 1(a)) through two intermediate stages (Figure 1(b) and 1(c)) to its final mature form (Figure 1(d)).

The model assumptions are based on the premise that unit costs of transport vary between modes, with the steepness of the cost curves reflecting the fact that, for volume movements, sea transport should be the cheapest per tonne$\mathrm{km}$, road transport should normally be the most expensive (at least over a certain distance), and waterway and rail costs should be intermediate. At ports and inland terminals, a freight handling charge is levied without any material progress being made along the supply chain; a vertical "step" in the cost curve therefore represents the costs incurred here. The height of the step is proportionate to the level of the charge. Depending on the route chosen, the combination of modes and cost will be different. The purpose is to find the most competitive route cost wise. The model may also be used as a contributory tool in the debate over the value of time in freight transport operations. Although this approach in itself is not new (Levander, 1993; Christopher, 1998), the portrayal of the cost components as increments along the transport chain is quite novel. 


\section{IJPDLM}

31,9

666

\section{Figure}

Cost model for multimodal transport

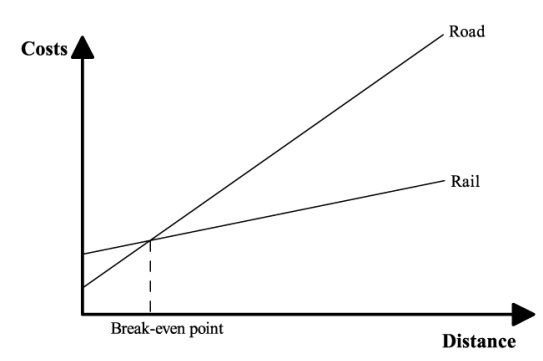

(a) Unimodal Alternatives, Road vs Rail

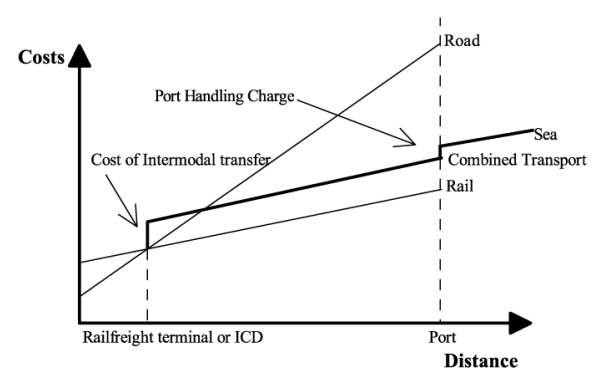

(c) Combined Transport, Road-Rail-Sea

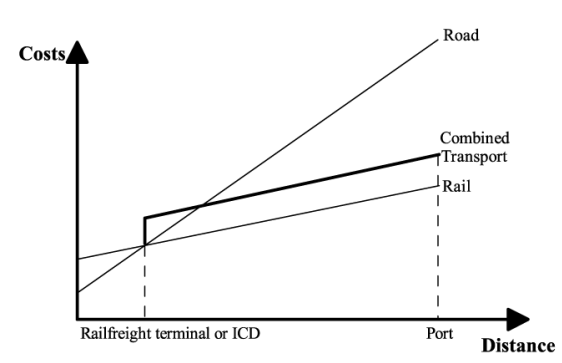

(b) Combined Transport, Road-Rail

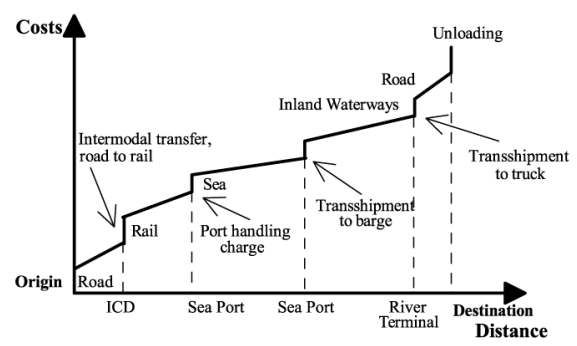

(d) Multimodal Transport, from Origin to Destination

Source: Adapted from Beresford (1999)

Beresford and Savides (1996; 1997), Beresford (1999) tested this model on the UK-Greece transport corridor. The model highlighted the factors and which affected the choice of transport modes or combination of modes for given movements. The model could also assist in the logistics trade-offs, such as those between speed and costs, to be thoroughly examined in a range of circumstances. A similar model was also used by Levander (1993) to illustrate the transport charges of paper from Finland to Germany.

\section{Limitations of the multimodal transport cost-model}

The choices of multimodal transport combinations are based on factors others than just transportation costs, which are directly related to transit time, distance, and intermodal transfer. Other issues such as the nature of freight, cargo value-density, marketing strategy, stockholding policy, risk of damage and pilferage, packing requirement, security, etc., can be at least as important. These issues need to be assessed and balanced with direct cost components in order to find the most appropriate multimodal transport combination for a particular commodity. It is acknowledged that analytical models, such as this multimodal transport cost-model, are based on some simplified assumptions. Nevertheless, this model can be helpful to the transport decision maker in the selection of routes and modes.

In this paper, the model is tested using real data over a series of alternative routes for export between Lao PDR and the European Union. Data was 
obtained either directly or through secondary data sources: from Lao exporters, importers, logistics service providers, Customs; Vietnamese transport service providers, port authorities, Customs; Thai transport operators, freight forwarders, ports and Inland Clearance Depot operators, Customs, Malaysian logistics service providers, railway, port, and Customs; Singapore logistics service providers, port authority, Customs; regional and international shipping lines.

\section{Risk analysis: the confidence index}

The significance of uncertainty for a decision situation depends on the cost of reversing a commitment once made. It is especially when high uncertainty is coupled with high cost that uncertainty needs to be acknowledged and allowed for in any risk analysis (Rosenhead, 1989). According to Hertz and Thomas (1984) risk means both uncertainty and the results of uncertainty. That is, risk refers to a lack of predictability about structure, outcomes or consequences in a decision or planning situation. In this case, how certain is the decision maker that the goods will arrive safely at destination after the selection of a particular multimodal transport solutions? The term "risk analysis" is used here to denote methods, which aim to develop a comprehensive understanding, and awareness of the risk associated with the decision involved in the selection of multimodal transport corridors. Moskowitz (1987) stated that all decision problems have certain general characteristics. These characteristics constitute the formal description of the problem and provide structure for solutions. The decision problem involving combinations of transport modes for exporters in Lao PDR may be represented in terms of the following four elements:

(1) The decision maker. The decision maker is responsible for making the decision. Lao shippers, freight forwarders and logistics providers are the decision makers.

(2) Alternative courses of action. An important part of the decision maker's task, over which he has control, is the specification and description of the alternatives that are specified. The research proposes five multimodal transport corridors to choose from for export to Europe.

(3) Events. Events are the scenarios or states of the environment not under the control of the decision maker (that may occur). Uncertainty is measured in terms of probabilities assigned to the events. Measurement of uncertainty for each mode of transport, intermodal transfer and other nodal activities is done via a confidence index. This confidence index is based on a five point type scale: $(1)=$ Almost no confidence; $(2)=$ not very confident; (3) = fairly confident; (4) = confident, and (5) = very confident.

(4) Consequences. The consequences that result from a decision depend not only on the decision maker but also on the event that occurs. The confidence index tries to capture some of the uncertainties involved in the selection of each multimodal transport corridor. These ratings reflect 
IJPDLM

31,9

668 the subjective values of the decision makers. The consequence will depend on the multimodal transport corridor chosen and the assigned confidence index. In theory, it will be the most competitive multimodal transport route.

The confidence index that is used for "risk analysis" in this paper is derived from the field of political science, especially political instability methodology. Qualitative predictive research in political (and economic) instability focuses on intuition, judgement and Delphi forecasting (Andriole and Hopple, 1983). Intuitive qualitative forecasting is central to a systematic analysis. All the persons interviewed for this study are knowledgeable about international trade transactions, transport operations, documentary procedures, and rules and regulations in their respective countries or region. The respondents intuitively assign a rating for each transport mode, intermodal transfer charge and other nodal activities. This intuition is based on the respondent's immersion in the history, culture, politics, experience in trading practices, transport operations, administrative procedures of their own country and up to a certain extent of their own region (Bruce, 1983). This confidence index or rating is accurate as long as the national and regional environment has not changed. It is very important to continually assess and monitor the situation in South East Asia. Turmoil in a country, changes in national or regional policies can have a significant impact on the selection of a particular multimodal transport corridor (Simon, 1983). This is particularly true in Cambodia, Lao PDR, Thailand and Vietnam where political and economic instability constantly affect the business environment. If changes occur, then there will be a need to re-evaluate which multimodal transport corridor is the most appropriate under the new circumstances. The same methodology can be used for the re-evaluation of the confidence index.

\section{Multimodal transport corridors routeing}

At the present moment there is no integrated transport or logistics system in place in the region but various multimodal transport corridors are available to users of the regional transport network. The smooth flow of freight within a multimodal transport corridor will determine its success. The case of Laotian garment exporters is taken to illustrate the point. The transport costs in this study are based on offers that were obtained by transport service providers such as freight forwarders, trucking firms, shipping lines, rail operators, port authorities which operate on Lao PDR's export routes. Prices quoted concern the shipment of 1 TEU (twenty foot equivalent unit) on a Freight All Kind (FAK) rate. Existing alternative routes and modal combinations for the movement of unitised freight between Lao PDR and Rotterdam in The Netherlands are summarised hereunder in Table I and illustrated in Figure 2 (see Appendix for a more detailed map of each route). 


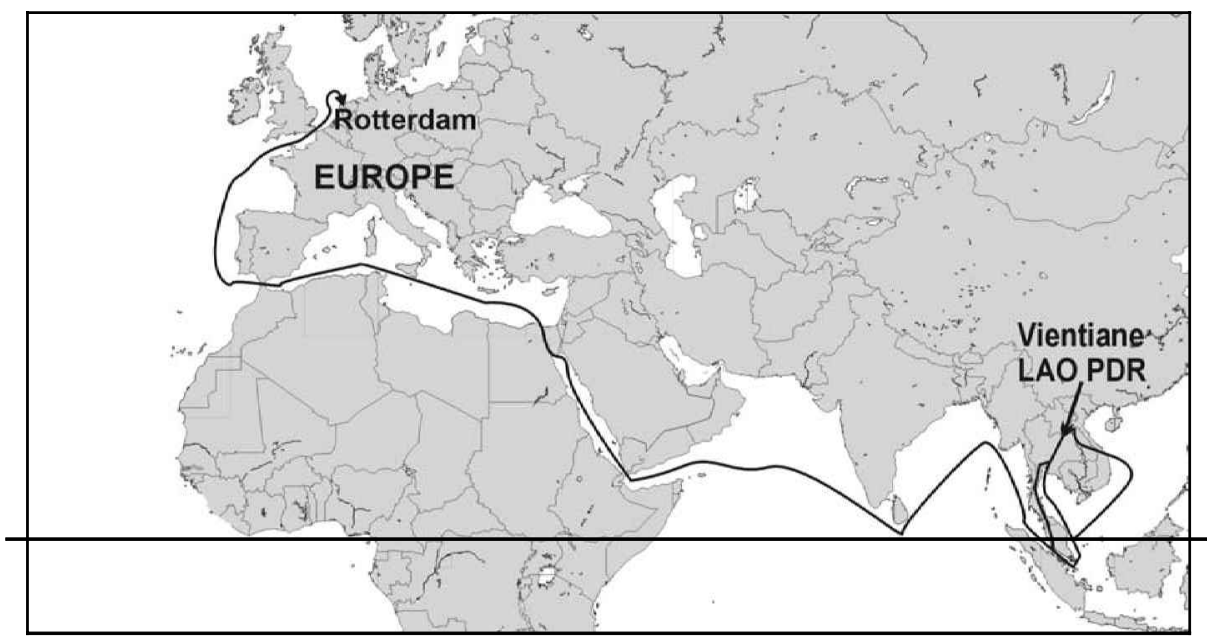

Multimodal transport

669

Routeing via Danang (Vietnam) (Route 1)

Route 1 (see Table II) has been chosen because this route represents the traditional route for Lao import and export. This is due to the fact that before the opening of the Lao economy, international trade was generally conducted with former communist countries and the only access to the sea that was available to Lao PDR was through Vietnam. Under a bilateral protocol, all transit traffic through Vietnam must utilise the Lao Bao (Lao PDR)-Houey Kaki (Vietnam) border crossing and Danang port as the point of entry or exit. The protocol relates to the issue of transit permit or authorisation for each shipment. The protocol does not cover the issue of movement of vehicles.

For goods in transit through Vietnam, a transit permit must be issued in Vietnam, by the Ministry of Trade, on Application by Lao Freight Forwarder (LFF) through the Lao Ministry of Commerce. The information on the permit from the Vietnamese Trade Ministry is then transcribed by Vietnamese Customs to create a transit document called "Import and Export Form for Transit Cargo". The routeing of documents from Vientiane to Hanoi to Danang port can take a few weeks whereas the actual transit time is not more than 3 to 4 days. If there are no administrative delays when the shipment leaves Vientiane on Monday, the container will arrive in Danang on Thursday with a feeder connection to Singapore on Friday and arrive in Singapore on Tuesday the following week.

The confidence index for this route is not very high at 2.7. This is due to the fact that there are too many uncontrollable factors, especially on the land leg of the journey. Transit via Vietnam is a difficult process. Discrepancies between ministerial agencies' strategies relating to transit cargo are one of the main reasons for the very low confidence index of the land leg from Vientiane to Danang. The confidence index for this particular route can be increased by providing financial incentives or through personal connections at strategic 


\begin{tabular}{|c|c|c|c|c|c|c|c|}
\hline \multirow[b]{2}{*}{$\begin{array}{l}\text { IJPDLM } \\
31,9\end{array}$} & \multirow{2}{*}{\multicolumn{2}{|c|}{ Day Leg }} & \multirow[b]{2}{*}{ Mode } & \multirow[b]{2}{*}{$\begin{array}{l}\text { Transit } \\
\text { time }^{\mathrm{a}}\end{array}$} & \multirow[b]{2}{*}{$\begin{array}{l}\text { Distance } \\
(\mathrm{km})\end{array}$} & & \\
\hline & & & & & & $\begin{array}{l}\text { Cost } \\
\text { (USD) }\end{array}$ & $\begin{array}{l}\text { Confidence } \\
\text { index }\end{array}$ \\
\hline \multirow{11}{*}{670} & \multirow[t]{2}{*}{1} & Vientiane-Danang & \multirow[t]{4}{*}{ Road } & 3 days & 1,060 & 750 & 1 \\
\hline & & LaoBao-Houei Kaki Customs & & \multirow[t]{3}{*}{2 hours } & 0 & 220 & $1^{\mathrm{b}}$ \\
\hline & 4 & Danang Charges & & & 0 & 20 & 3 \\
\hline & & THC & & & 0 & 1 & 2 \\
\hline & \multirow[t]{2}{*}{5} & Feeder Connection & & 1 day & 0 & - & 3 \\
\hline & & Danang-Singapore & \multirow[t]{3}{*}{ Sea } & 4 days & 1,910 & 400 & 3 \\
\hline & 9 & Singapore Charges & & & 0 & 59 & 4 \\
\hline & 10 & Tranship waiting time & & 1 day & 0 & _. & 4 \\
\hline & \multirow[t]{3}{*}{31} & Singapore-Rotterdam & \multirow[t]{3}{*}{ Sea } & 21 days & 15,359 & 1,270 & 4 \\
\hline & & Other handling charges ${ }^{c}$ & & & 0 & 700 & 2 \\
\hline & & Total & & $31 / 32$ days & 18,329 & 3,420 & 2.7 \\
\hline
\end{tabular}

Table II.

Vientiane-DanangSingapore-Rotterdam

Notes: ${ }^{a}$ Assuming no delays; ${ }^{\mathrm{b}}$ This confidence rating can be improved with the payment of a higher customs charge or other types of financial incentives; ${ }^{c}$ Include profit

Source: Industry sources

nodal links such as the Lao Bao (Lao PDR)-Houey Kaki (Vietnam) border crossing. The sea leg is less problematic and more reliable.

It is interesting to note that, as expected, the sea leg is the most important leg constituting 94 percent of the total journey by distance, but only 49 percent of the total transport cost. Other charges (including Customs) represent more than 29 percent of the total transport cost whereas road transport comprises 22 percent of the total transport cost. The price obtained through this route is the highest (3,420 USD/TEU) of all the routes with the longest transit time (31/32 days), but is quite representative of trading routes where the freight flows are not very important and subject to very strong imbalance. Currently there are only three scheduled feeder ships from Singapore with a capacity of 300-350 TEUs calling at Danang per week, whereas Singapore as a global hub has main line connection to Europe every day. Terminal handling charge is still quite minimal at the moment at only 1 USD. Figure 3 shows the movement graphically.

Transit through Vietnam has been difficult because of the poor condition of east-west roads as a result of user damage. Although the road from Danang to Lao Bao has been repaired, the movement of goods along this route is still hampered by very poor roads in Lao PDR. An appraisal of the inland leg from Vientiane to Danang shows that Customs costs represent 22 percent of the total inland transport cost. The trucking rate for this route is at $70 \mathrm{cents} / \mathrm{km}$. Figure 4 represents the inland leg for Route 1.

\section{Routeing via Bangkok (Thailand) (Route 2)}

As Lao PDR's trade has moved from communist countries to the European Union, North America and ASEAN, the ocean routeing has had to shift from utilising Danang port to Bangkok. Thailand is a regional hub with daily feeder connections to Singapore. 
Route 2 (see Table III) is the preferred route by Lao exporters. Movement of traffic through Thailand between Lao PDR and a third country is governed by a "Transit Transport Agreement" between the two governments, first signed in 1978 and renewed annually[4]. This provides for forwarding and transport to be carried out by authorised and certified operators.

The confidence index for this route is slightly higher than for the transit route via Vietnam at 2.89. This index would have been up to the "confident" level if the "tea-money" factor were not included. Similar to the route via Vietnam, areas of low confidence are at the border crossing between Lao PDR and Thailand. Offering financial incentives for speedier and reliable customs processing can again increase this confidence. Tea money must also be paid at Bangkok port for port services. Non-payment will result in disappearance or non-loading of cargo on feeder ship.

Most of the problem for transit traffic concerns import cargo where significant delays occur. There are fewer difficulties for export cargo compared

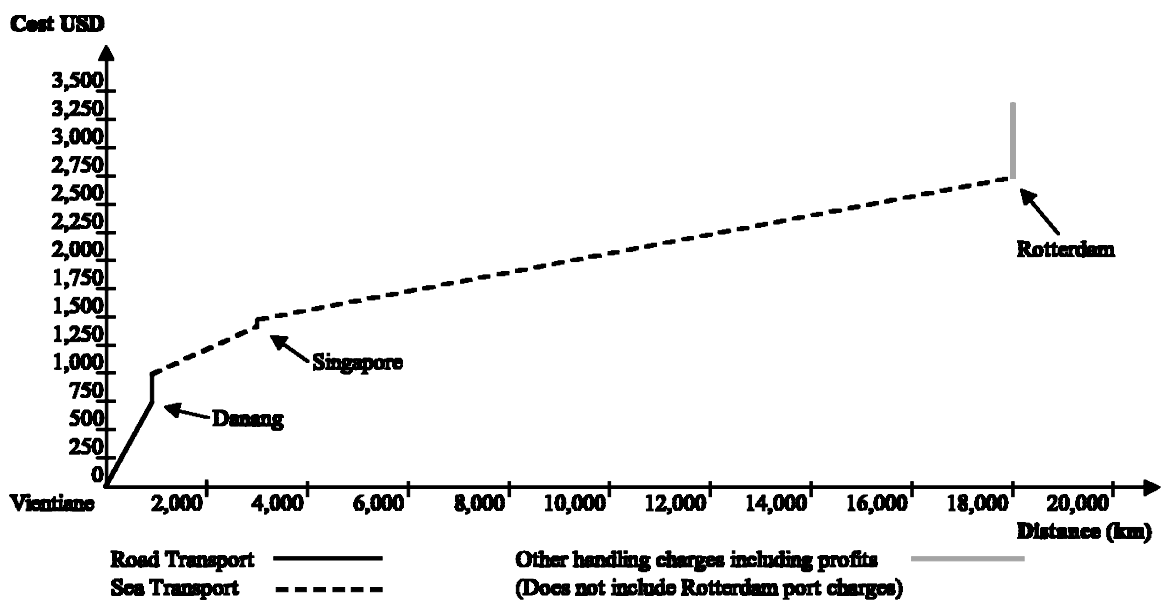

Figure 3. Vientiane-DanangSingapore-Rotterdam (Route 1)

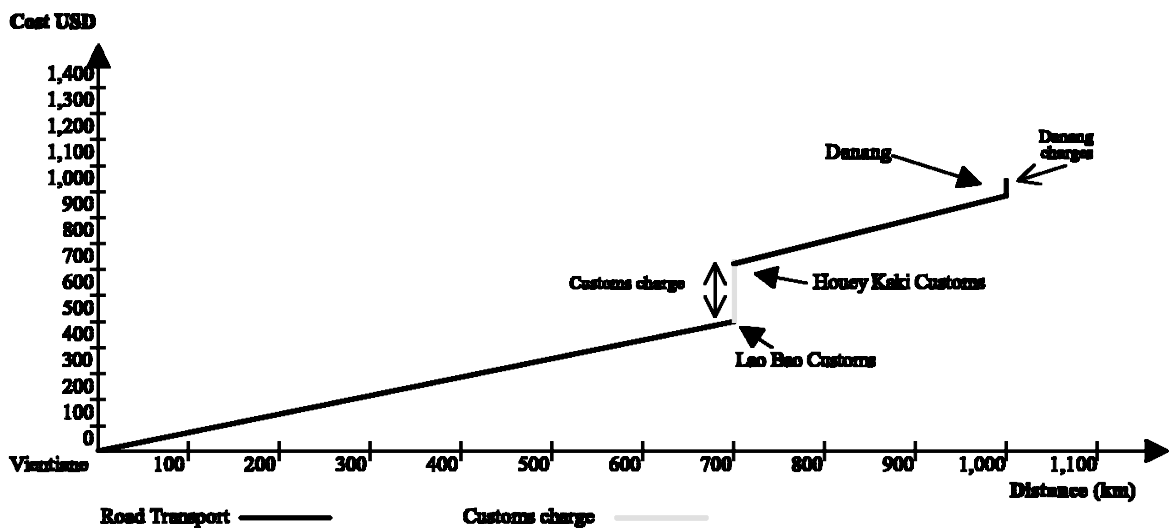

Figure 4. Vientiane-Lao BaoHouey Kaki-Danang 
IJPDLM

31,9

672

to the administrative impediments that may be encountered when transiting through Vietnam; also the distance from Vientiane to Bangkok $(650 \mathrm{~km})$ is shorter than to Danang $(1060 \mathrm{~km})$. The transit time is also much more competitive with only one day from Vientiane to Bangkok compared to 3 to 4 days (if all the paperwork is in order) to Danang. The total transport cost via Bangkok to Rotterdam is 2,476.8 USD with a transit time of 30/31 days. As expected, the sea leg is again the dominant mode with more than 96 percent of the total journey by sea and represents around 60 percent of the total transport cost. Other charges (including Customs) are not as high as on the VientianeDanang route as they only represent a little more than 12 percent of the total transport cost (see Figure 5).

A closer analysis of the Vientiane-Bangkok leg (see Figure 6) reveals that the most expensive inland leg is from Vientiane to Thanaleng which is the Laotian transit warehouse cum border post opposite of Nongkhai in Thailand as the freight rate for this leg is $3.6 \mathrm{USD} / \mathrm{km}$. The border crossing in itself represents

\begin{tabular}{|c|c|c|c|c|c|c|}
\hline Day & Leg & Mode & $\begin{array}{l}\text { Transit } \\
\text { time }^{\mathrm{a}}\end{array}$ & $\begin{array}{l}\text { Distance } \\
(\mathrm{km})\end{array}$ & $\begin{array}{l}\text { Cost } \\
\text { (USD) }\end{array}$ & $\begin{array}{l}\text { Confidence } \\
\text { index }\end{array}$ \\
\hline \multirow[t]{7}{*}{1} & Vientiane-Thanaleng & Road & 1 hour & 13 & 47 & 3 \\
\hline & Thanaleng-Bangkok & Road & 23 hours & 637 & 315 & 3 \\
\hline & Document charge & & & 0 & 50 & 3 \\
\hline & Customs ${ }^{\mathrm{b}}$ : & & & 0 & & \\
\hline & Lao side & & & & 13 & 2 \\
\hline & Thai side & & & & 26 & 2 \\
\hline & Transit entry document & & & 0 & 5 & 2 \\
\hline \multirow[t]{9}{*}{2} & Bangkok port: & & 1 day & 0 & & \\
\hline & 1. Container stevedorage & & & & 21 & 3 \\
\hline & 2. Container wharfage & & & & 22 & 3 \\
\hline & 3. Lift on/off charges & & & & 17 & 3 \\
\hline & 4. $\mathrm{THC}$ & & & & 68 & 3 \\
\hline & $\mathrm{B} / \mathrm{L}$ charge & & & 0 & 13 & 3 \\
\hline & Tea money & & & 0 & & \\
\hline & customs & & & & 6.7 & 1 \\
\hline & port & & & & 14.1 & 1 \\
\hline 3 & Feeder connection & & 1 day & 0 & - & \\
\hline 4 & Bangkok-Singapore & & 4 days & 1,540 & 230 & 4 \\
\hline 8 & Singapore charges ${ }^{\mathrm{d}}$ & & & 0 & 59 & 4 \\
\hline 9 & Tranship waiting time & & 1 day & 0 & - & 4 \\
\hline \multirow[t]{3}{*}{30} & Singapore-Rotterdam & Sea & 21 days & 15,359 & 1,270 & 4 \\
\hline & Other handling charges ${ }^{\mathrm{d}}$ & & & 0 & 300 & 3 \\
\hline & Total & & 30/31 days & 17,549 & $2,476.8$ & 2.89 \\
\hline
\end{tabular}

Notes: ${ }^{a}$ Assuming no delays; ${ }^{\mathrm{b}}$ Personal connections and financial incentives can help

Table III.

Vientiane-Bangkok-

Singapore-Rotterdam increase Customs' confidence index; ${ }^{c}$ This is the minimum amount required for normal service; ${ }^{\mathrm{d}}$ Include profit

Source: Industry sources 
20 percent of the transport cost up to Bangkok port with 12 percent going into document charges and 8 percent into tea money.

Bangkok port is also quite expensive to use, as the shipper will have to pay a staggering 161.8 USD per container. Terminal handling charges (THCs) represents 42 percent of the charges that are incurred at Bangkok port. "Tea money" represents roughly 13 percent of the local charges. The Port Authority of Thailand has tried to eradicate "tea money" but was unsuccessful as workers adopted a "go-slow" attitude resulting in major delay and congestion in the port area during early 1999. THC has also come under the scrutiny of the Thai Ministry of Commerce but without much success as liner operators did not accept the lowering of their THC charge. The shipping lines were arguing that since the various authorities were not able to stop "tea money", this cost will need to be included in their THC.

\section{Routeing via Laem Chabang (Thailand) (Route 3)}

For cargo that exits through the port of Laem Chabang (Route 3, Table IV), the procedures are the same as for cargo having to go through Bangkok port. Nonetheless, this route is marginally more expensive by going through Thailand at a total price of 2,503 USD per TEU although there is no difference in the total transit time (see Figure 7).

The confidence index is higher than going through Bangkok port at 3.1. This is due to the fact that there is no tea money involved at Laem Chabang port. Crossing the border between Thanaleng (Lao PDR) and Nongkhai (Thailand) is still the weakest point of the network but as soon as the goods are in Thailand the transport system is reliable enough to warrant its rating of "confident".

The sea leg of the voyage represents 61 percent of the total transport cost while road transport represents 17 percent of the total transport cost. For the total distance, road transport is only 4 percent of the total journey. Other charges are also less significant when going through Laem Chabang, as there is no tea money (see Figure 8).

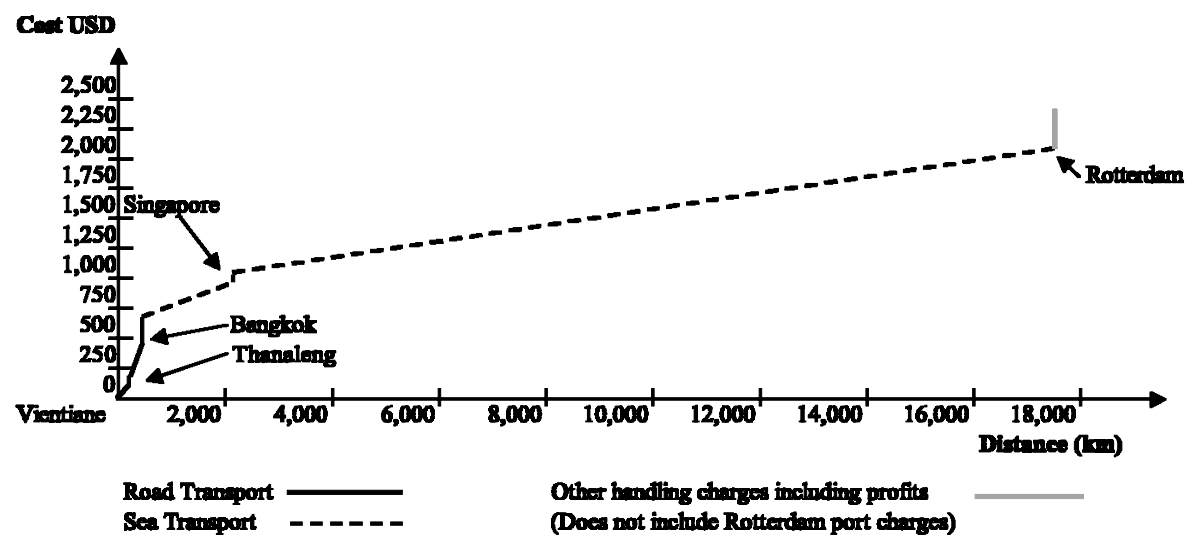

Figure 5. Vientiane-BangkokSingapore-Rotterdam (Route 2) 
IJPDLM

31,9

674

Figure 6.

Vientiane-Thanaleng-

Nongkhai-Bangkok

Table IV.

Vientiane-Laem

Chabang-Singapore-

Rotterdam

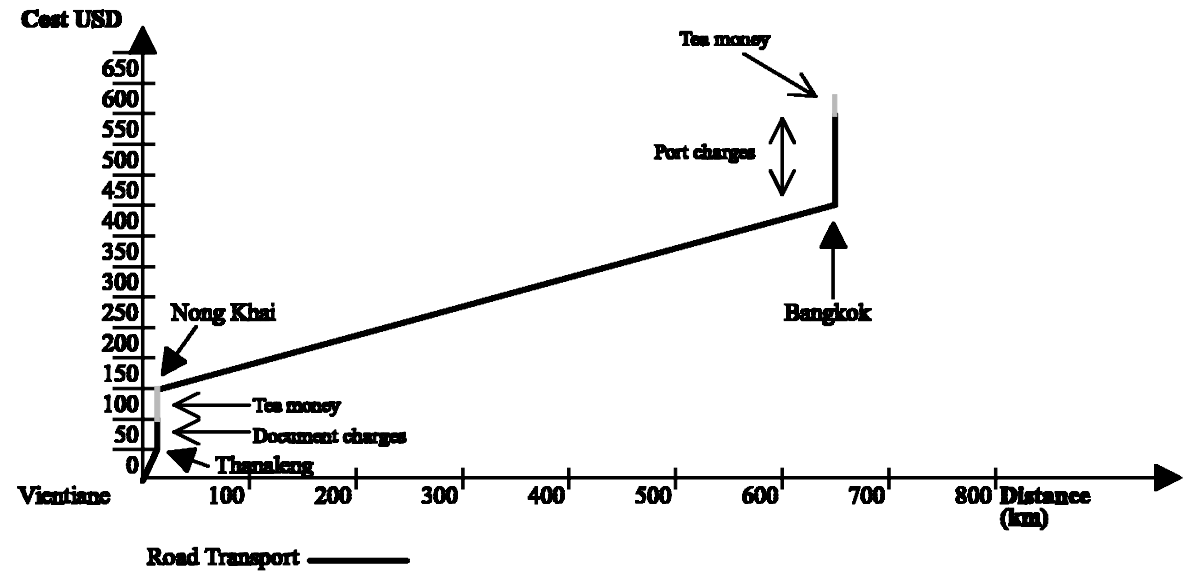

Source: The authors

Notes: ${ }^{\mathrm{a}}$ Assuming no delays; ${ }^{\mathrm{b}}$ Include profit

Source: Industry sources

Laem Chabang is currently the most important deep-sea port in Thailand in terms of volume. The annual throughput for 1998 was at 1,424,702 TEUs[5]. The reason for Laem Chabang growth is due to the Thai Government's policy 


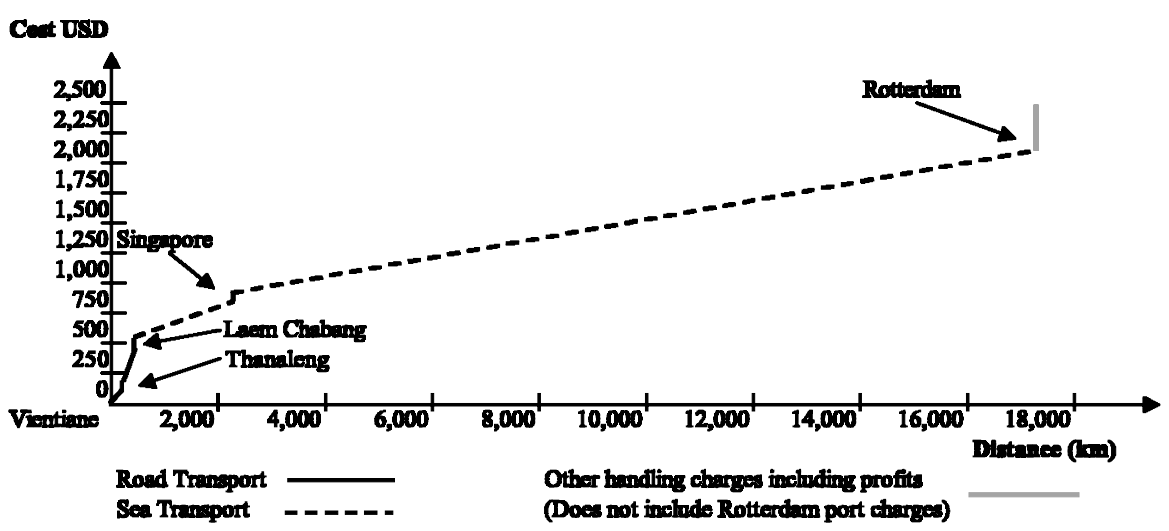

Multimodal transport 675

Figure 7.

Vientiane-Laem Chabang-SingaporeRotterdam

to divert traffic from Bangkok port (which is a river port located in the centre on the city) to Laem Chabang port. The operation of Laem Chabang port is also very different to that of Bangkok port. Bangkok port is operated by the Port Authorities of Thailand whereas Laem Chabang's operations are under private concessions. These differences in the management of both ports have been reflected in their working practices, efficiency and charges.

Laem Chabang as the most important deep-sea port has a daily feeder connection to Singapore. Main line ships also call at Laem Chabang for the Trans-Pacific trade on a weekly basis. It is worth noting that there are no mainline ships destined for Europe. All the cargo for the Middle East and Europe must be transhipped in Singapore first.

When analysing the inland leg from Vientiane to Laem Chabang, the port charges only represent 12 percent of the inland transport cost compared to 26 percent for Bangkok port. The transit charge between Thanaleng and Nongkhai (including Customs and document charges) still represents around

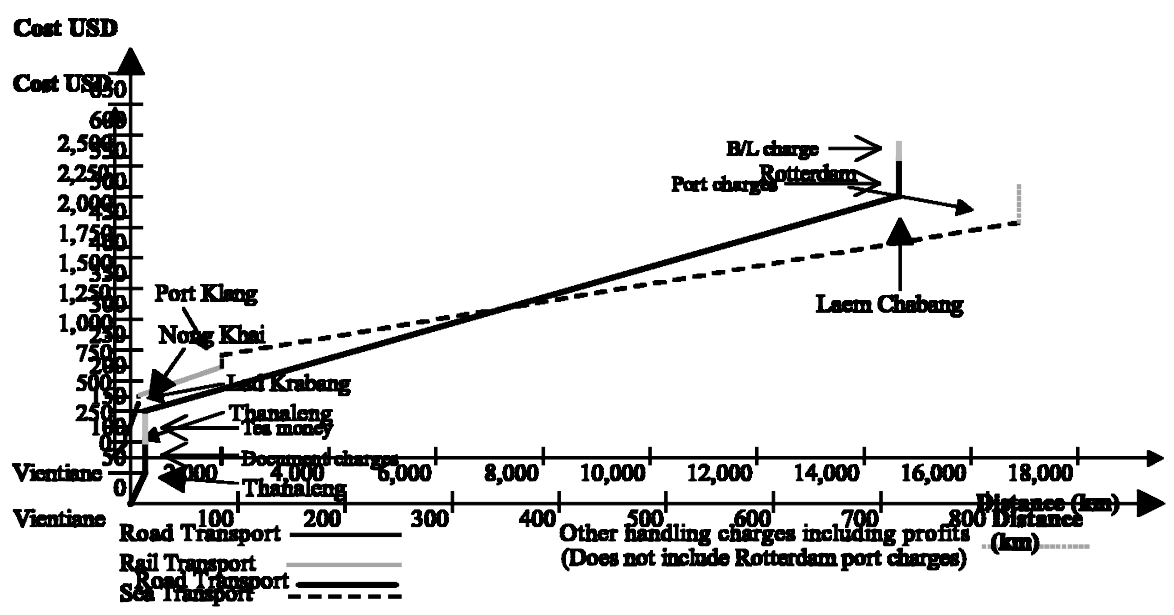

Soufre: The atthers

Figure 8. Vientiane-ThanalengNongkhai-Laem Chabang 
IJPDLM

31,9

676

Figure 12.

Vientiane-Thanaleng-

Nongkhai-Lad KrabangPort Klang

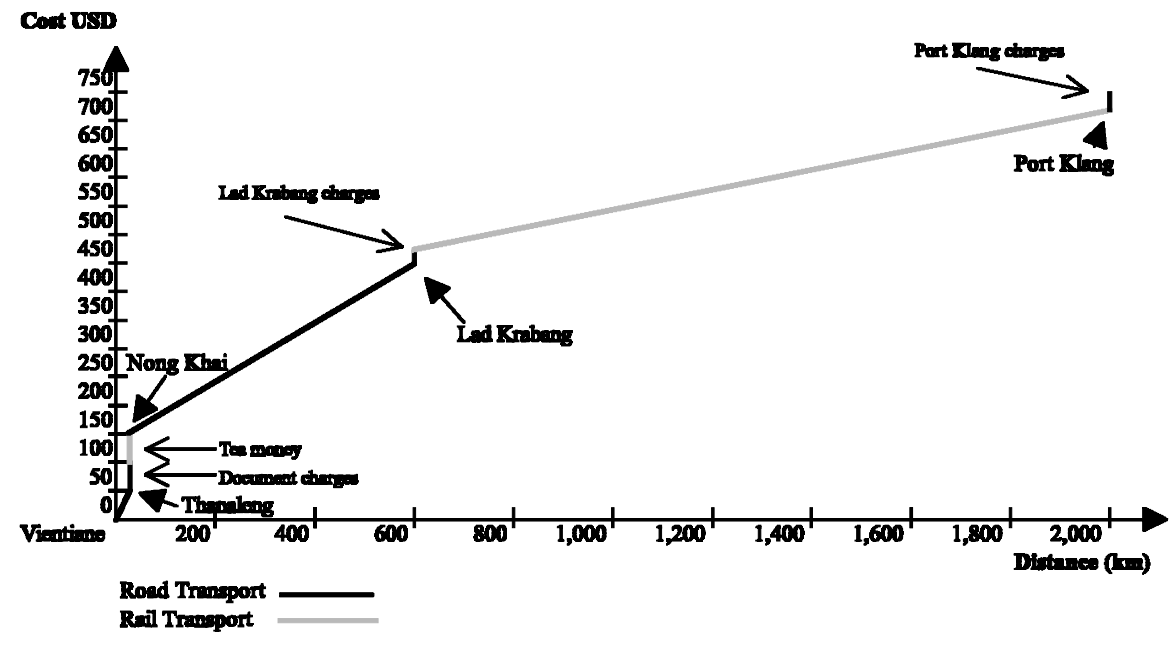

Source: The authors

17 percent of the total inland transport cost. The trucking rate is 13 percent higher than when going to Bangkok at 362 USD compared to 315 USD but with no real difference in transit time.

Routeing via Lad Krabang (Thailand) (Route 4)

Route 4 (see Table V). This route is via Lad Krabang which is an Inland Clearance Depot (ICD) located in the outskirts of Bangkok with a direct rail link to Laem Chabang. An ICD is sometime referred to as a "dry port". According to Beresford and Dubey (1990) "dry ports" are specific sites to which imports and exports can be consigned for inspection by Customs and which can be specified as the origin or destination of goods in transit with documentations such as a multimodal transport bill of lading $(\mathrm{B} / \mathrm{L})$.

The ICD promotes the concept of multimodal transport, as the consignment can remain unbroken but at the same time also has far-reaching implications for infrastructure requirements and transport organisation. It relieves the port storage problems (Banomyong et al., 1999) but, at the same time, requires a certain minimum standard of road, rail or waterways connection between the port and the inland depot.

The use of this route is marginally more expensive than the Vientiane direct to Laem Chabang route, from 2,503 USD/TEU to 2,518.5 USD/TEU. The confidence index is slightly lower at 3 . This is because rail transport is not considered as reliable as road transport between Lad Krabang and Laem Chabang. This intermodal link is promoted by the State Railway of Thailand to ease road congestion to Laem Chabang port but presently the service is not reliable enough, and has diverted a lot of cargo to go by road between Lad Krabang and Laem Chabang[6]. 


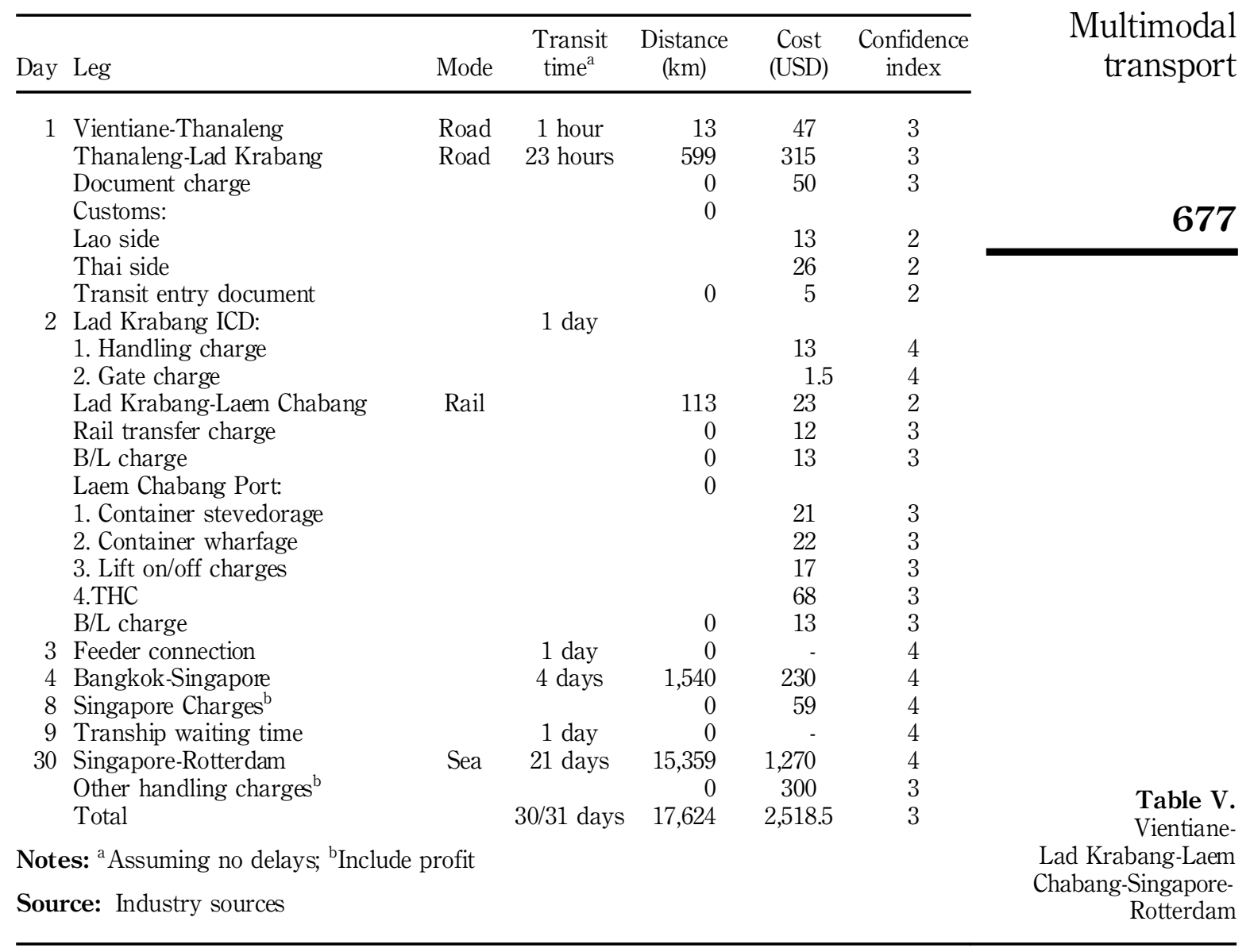

The total transit time for the journey to Rotterdam is the same. It is worth noting that the ICD and rail freight only represent 2 percent of the total transport cost. The sea leg is still the most important with more than 61 percent of the total transport cost and 96 percent of the total journey (see Figure 9).

The capacity of the Lad Krabang ICD is designed to handle 400,000 TEU per annum with a modal split of 52.8: 47.2 between rail and road in 1998. Road transport to Laem Chabang is possible but emphasis is on the promotion of block train services from Lad Krabang to Laem Chabang through competitive rates (13 USD/TEU). Currently the average load factor for the train services is at 78 percent. Figure 10 gives a more precise indication of the minimal increase in cost when transiting through Lad Krabang ICD complex, even though there is a modal change in the process. 


\section{IJPDLM}

31,9

\section{8}

Figure 9.

Vientiane-Lad Krabang-

Laem Chabang-

Singapore-Rotterdam

Figure 10.

Vientiane-Thanaleng-

Nongkhai-Lad KrabangLaem Chabang
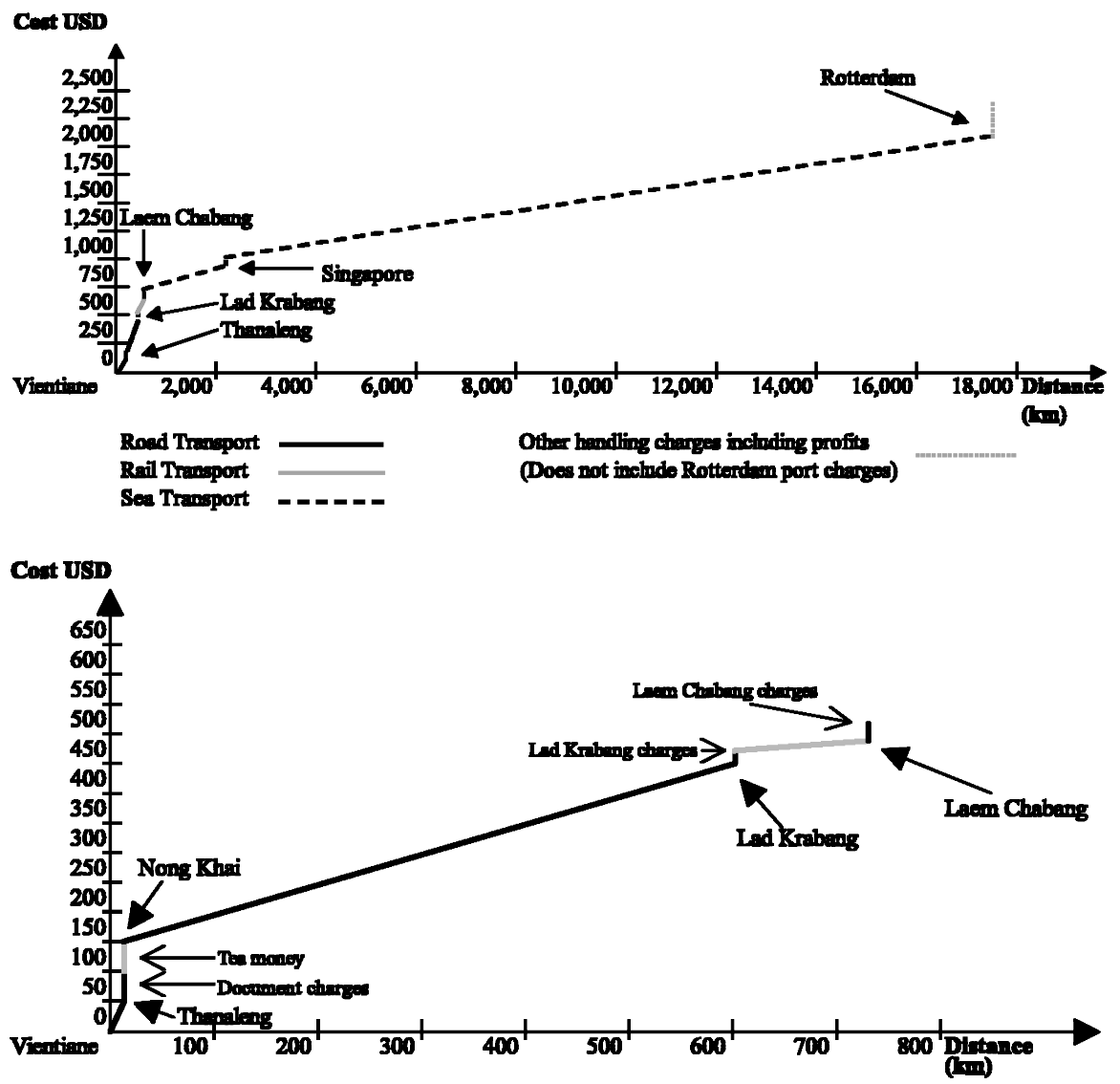

Roed Transport Rail Transport

Routeing via Port Klang (Malaysia) (Route 5)

Route 5 (see Table VI). This route is the most challenging as it has only been in operation since June 1999. From the findings, this route seems to be the most competitive for rate and transit time. The freight rate is at 2,467.5 USD/TEU with a total transit time of $27 / 28$ days. The confidence index is also quite good at 3. Even though the rail link between Thailand and Malaysia is quite new, it is now quite reliable, with at least one arrival and departure per day. The confidence index for rail transport is higher than between Lad Krabang and Laem Chabang because the trains are not operated by the governmental agencies such as the State Railways of Thailand or KTM of Malaysia.

Figure 11 gives a graphical representation of the freight movement where rail freight represents 15 percent of the total transport cost and 8 percent of the total journey, while the sea leg represents 53 percent of the total transport cost and 88 percent of the total journey. The road transport share of the 


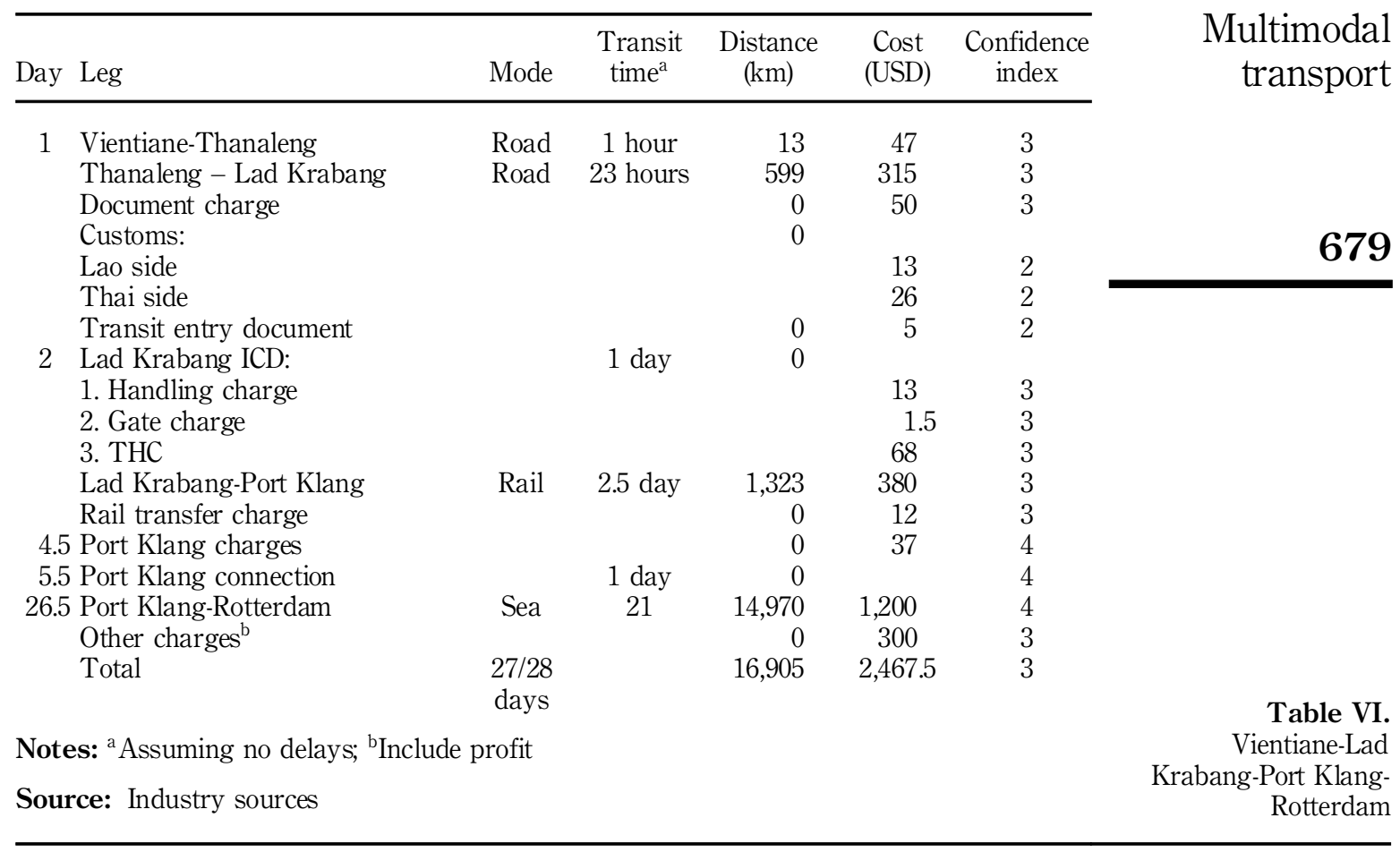

total transport cost is still at 15 percent with more than 20 percent of the total transport cost taken by other charges.

This Lad Krabang-Port Klang land bridge is expected to move 20,700 TEU by the end of 1999[7]. Each block train has a capacity of 50 TEU per trip and the trains are now running 14 times a week. The shipment leaving Vientiane on Monday, will arrive at Lad Krabang on Tuesday and leave for Port Klang on Wednesday. The actual transit time is 60 hours ( 2.5 days) from Lad Krabang to Port Klang. The advantage of the service is that the transit time from Port Klang to Lad Krabang has been shortened compared to between five to seven days by sea and four days by road. Port Klang may not be as big as Singapore port but is still an important regional hub port with a throughput of more than 1,813,348 TEU in 1998, and daily connection to the main European ports. Customs procedures for this land bridge is done at the Lad Krabang ICD so there is no need for the goods to be cleared at the Malaysian border of Padang Besar. It is Malaysia's policy to promote Port Klang as a regional load-centre and transhipment hub in order to compete with Singapore. This is done by offering special rates for cargo that transit through Port Klang, from 50 USD/TEU for cargo originating from Malaysia to 37 USD for third country cargo. Free storage up to 28 days is also provided for transit cargo. Figure 12 represents the inland transport cost up to Port Klang. 
IJPDLM

31,9

\section{Conclusions}

Of all the alternative journeys between Vientiane and Rotterdam, the routeing via Port Klang achieves the most competitive costs and transit time with a reasonable confidence index. It must be noted that in reality, sea freight rates are not stable and are adjusted for "peak season" surcharge, or other types of surcharges which may increase the freight rates compared to those obtained during this study.

The ICDs in Lad Krabang also achieve significantly lower container handling costs than port terminals. According to Beresford and Savides (1997), this difference probably occurs because maritime terminals have more sophisticated handling equipment and more complex infrastructure than inland multimodal terminals.

Currently, Laotian exporters to Europe are not really aware of the multimodal alternatives that are offered to them via Thailand. This might be due to the fact that most of these garment exporters prefer to sell their product FOB Thanaleng or FOB Bangkok, thus not controlling the transport chain. If Laotian exporters want to benefit from the various route options that are offered to them, then they will have to negotiate their international trade under "delivered" trade terms. These "delivered" trade terms will assist in the control of the transport chain, as Laotian exporters will be able to nominate the main carriers and choose the most suitable route.

When comparing the costs involved in these routes, sea transport is as expected the cheapest per cost $/ \mathrm{km}$, rail is intermediate and road transport is the most expensive (see Table VII). It is also worth noting that the various other charges are still a burden to the competitiveness of Laotian exports. On certain routes, such as via Bangkok, transit and local charges represent up to 10 percent of the total transport cost, with "tea money" representing 2 percent. The figure might not be very high, but this 2 percent does represent a loss in terms of the Laotian trade competitiveness.

Multimodal transport corridors enable economies of scale within a transportation system where modes are used in the most productive manner. The globalisation of trade is largely dependent on transportation systems with reliable transit times and costs. Exporters and logistics service providers must re-evaluate their strategies for freight transportation as all modes and all possible transfers between modes must be considered. With the development of new modal and multimodal infrastructure in the region, Lao PDR has a growing accessibility to the international market.

The paper has demonstrated that the best possible route for Laotian garment exporters to Europe is via Port Klang in Malaysia, both on total transport costs and transit time (see Table VIII). The only possible reservation concerning such a route is the road haulage factor from Nongkhai to Lad Krabang or Bangkok. This is due to the fact that most trucks are overloaded and claims on road freight (damage, loss of goods, etc.) are excessively high for some cargo. It might be possible to utilise the rail link between Nongkhai and Lad Krabang or Bangkok but all this will depend on the frequency, reliability 
and cost of the service offered. There is currently a project linking Nongkhai to Vientiane but because of the 1997/1998 economic crisis the project has been shelved by the Thai concessionaire.

The recognition of transport logistics, and in particular multimodal transport, as a vital element in export and import has changed the way business is done forever. Multimodal transport has arisen as a result of customers' demands for more efficient, rapid, and reliable deliveries (Andersson and Hasson, 1998).

This paper does not claim to be fully exhaustive, but it is hoped that this case study will provide a foundation for research in transport and logistics, especially in South East Asia. Below are some other suggestions for possible future research:

- To explore the decision-making processes in international freight transport routeing and modal choices in Cambodia, Malaysia, Myanmar, Singapore, Thailand, Vietnam or even South East Asia as a whole.

- To measure the efficiency and competitiveness of multimodal transport corridors in other countries with comparable constraints of access and low economic development.

- To compare logistics decision making in developed countries with those in developing countries.

- To explore the effect of informal payments and other non-physical impediments on global supply chain reliability.

- To use the model in an adapted form in order to investigate the value placed on time by different parties.

\begin{tabular}{lllc}
\hline Route & Mode & $\begin{array}{c}\text { Cost/km } \\
\text { (USD) }\end{array}$ & $\begin{array}{c}\text { Confidence } \\
\text { index }\end{array}$ \\
\hline (1) Vientiane-Danang & Road & 0.7 & 1 \\
Danang-Singapore & Sea (feeder) & 0.21 & 3 \\
Singapore-Rotterdam & Sea (main) & 0.08 & 4 \\
(2) Vientiane-Bangkok & Road & 0.55 & 3 \\
Bangkok-Singapore & Sea (feeder) & 0.15 & 4 \\
Singapore-Rotterdam & Sea (main) & 0.08 & 4 \\
(3) Vientiane-Laem Chabang & Road & 0.55 & 3 \\
Laem Chabang-Singapore & Sea (feeder) & 0.15 & 4 \\
Singapore-Rotterdam & Sea (main) & 0.08 & 4 \\
(4) Vientiane-Lad Krabang & Road & 0.59 & 3 \\
Lad Krabang-Laem Chabang & Rail & 0.2 & 2 \\
Laem Chabang-Singapore & Sea (feeder) & 0.15 & 4 \\
Singapore-Rotterdam & Sea (main) & 0.08 & 4 \\
(5) Vientiane-Lad Krabang & Road & 0.59 & 3 \\
Lad Krabang-Port Klang & Rail & 0.28 & 3 \\
Port Klang-Rotterdam & Sea (main) & 0.08 & 4 \\
\hline
\end{tabular}

Multimodal transport

681

$\square$ 
IJPDLM

31,9

682

This list is only a suggestion of possible future research. There are many more areas that need to be researched further, even within the context of multimodal transport corridors in South East Asia. An area of considerable interest could also be the proportion of costs tied up in sea transport, road transport, rail transport, ports, tea-money, etc., in South East Asia versus in Europe or in other countries or regions. This type of multimodal transport corridor approach, with the transport cost model and the confidence index at its core, could be used as a methodology to "benchmark" logistics performance: within regions, between regions, within countries, between countries, and finally on a continental or a global scale.

\section{Notes}

1. Lao PDR, China (Yunnan Province), Vietnam, Myanmar, Cambodia and Thailand.

2. Lao PDR, Vietnam, Myanmar, Cambodia, Thailand, Malaysia, Singapore, Philippines, Brunei and Indonesia.

3. Adopted on 16 December 1998, in Hanoi, Vietnam.

4. This agreement has not been renewed for 1999.

5. Containerisation International Yearbook 1999.

6. Road and rail freight price are very similar.

7. The Star Maritime, 6 September 1999, Internet edition.

\section{References}

Allen, B., Mahmoud, M. and McNeil, D. (1985), "The importance of the time in transit and reliability of transit time for shippers and carriers", Transportation Research B, Vol. 19B No. 5, pp. 447-56.

Andersson, T. and Hasson, P. (1998), "Why integrated transport systems?", OECD Observer, No. 211 April/May, pp. $27-31$.

Andriole, S.J. and Hopple, G.W. (1983), "An overview of political instability research methodologies: basic and applied recommendations for corporate analyst”, in Rogers, J. (Ed.), Global Risk Assessment: Issues, Concept and Applications, Global Risk Assessment Inc., Riverside, Ca, pp. 75-97.

Banomyong, R. (1999), "Issues and challenges arising from multimodal transport in the ASEAN region", Paper presented to the Maritime Institute of Malaysia, 13 May 1999.

Banomyong, R., Nair, R.V. and Beresford, A.K.C. (1999), Managing Demand Amplification in the Supply Chain: the Thai Forwarders' Experience, Occasional Paper No. 59, Department of Maritime Studies and International Transport, Cardiff University, Cardiff.

Table VIII.

Total transport costs and transit times
Total transport cost

Route

(1) Via Danang (Vietnam)

(2) Via Bangkok (Thailand)

(3) Via Laem Chabang (Thailand)

(4) Via Lad Krabang (Thailand)

(5) Via Port Klang (Malaysia)
(USD)

3,420

$2,476.8$

2,503

$2,518.5$

$2,467.5$
Total transit time (days)

$31 / 32$

$30 / 31$

$30 / 31$

$30 / 31$

$27 / 28$ 
Barnhart, C. and Ratliff, D.H. (1993), "Modeling intermodal routing", Journal of Business Logistics, Vol. 14 No. 1, pp. 205-23.

Beresford, A.K.C. (1999), "Modelling freight transport costs: a case study of the UK-Greece corridors", International Journal of Logistics: Research and Applications, Vol. 2 No. 3, pp. 229-46.

Beresford, A.K.C. and Dubey, R.C. (1990), Handbook on the Management and Operations of Dry Ports, UNCTAD, RDP/LDC/7, Geneva.

Beresford, A.K.C. and Savides, K. (1996), The UK-Greece Transport Corridors: Routes and Modes, Occasional Paper No. 40, Department of Maritime Studies and International Transport, Cardiff University, Cardiff.

Beresford, A.K.C. and Savides, K. (1997), The UK-Greece Transport Corridors: A Case Study on the Logistics of Whisky Movement, Occasional Paper No. 45, Department of Maritime Studies and International Transport, Cardiff University, Cardiff.

Bertazzi, L., Speranza, M.G. and Ukovich, W. (1997), "Minimization of logistics costs with given frequencies", Transportation Research B, Vol. 31B No. 4, pp. 327-40.

Bezy, P.Y. (1996), "East-west corridor study”, Third Project Steering Committee Meeting, Transit Facilitation, ESCAP, Lao PDR-Thailand-Vietnam, Danang, 9-11 February 1996.

Blummenfeld, D.E., Burns, L.D. and Diltz, D.J. (1985), "Analysing trade-offs between transportation, inventory and production costs on freight networks", Transportation Research B, Vol. 19B No. 5, pp. 361-80.

Boerne, G.L. (1990), "An examination of the influences on the change of freight transport mode", unpublished MSc. thesis, Department of Maritime Studies and International Transport, UWCC, Cardiff.

Bruce, D. (1983), "Integrating political risk methodologies at a California International Bank", in Rogers, J. (Ed.), Global Risk Assessment: Issues, Concept and Applications, Global Risk Assessment Inc., Riverside, CA, pp. 131-9.

Carter, J.R. and Ferrin, B.G. (1995), "The impact of transportation costs on supply chain management", Journal of Business Logistics, Vol. 16 No. 1, pp. 189-212.

Christopher, M. (1998), Logistics and Supply Chain Management: Strategies for Reducing Cost and Improving Service, Prentice Hall, Harlow.

ESCAP. (1997), Assistance to Small and Medium-sized Enterprises for Enhancing their Capacity for Export Marketing, United Nations, ST/ESCAP/1816, New York, NY.

Fowkes, A.S., Nash, C.A. and Tweddle, G. (1989), Valuing the Attributes for Freight Transport Quality, Institute of Transport Studies, Working Paper 276, Leeds University, Leeds.

Hayuth, Y. (1986), Intermodality: Concept and Practice, Lloyds of London, Colchester.

Hayuth, Y. (1992), "Multimodal freight transport", in Hoyle, B.S. and Knowles, R.D. (Eds), Modern Transport Geography, Chapter 11, Belhaven, London.

Hertz, D.B. and Thomas, H. (1984), Risk Analysis and its Application, John Wiley \& Sons, Chichester.

Jung, T.-Y. (1994), Intermodal Development on China's Railways, Occasional Paper No. 24, Department of Maritime Studies and International Transport, Cardiff University, Cardiff.

Levander, K. (1993), "The potential for fast ships in European freight transport", in Wijnost, I., Peeters, C. and Liebman, P. (Eds), European Shortsea Shipping, Lloyd's of London Press, London.

Liberatore, M.J. and Miller, T. (1995), "A decision support approach for transport carrier and mode selection”, Journal of Business Logistics, Vol. 16 No. 2, pp. 85-111.

Marlow, P.B. and Boerne, G.L. (1992), The Case for Inter-modalism in Freight Transport, Occasional Paper No. 3, Department of Maritime Studies and International Transport, Cardiff University, Cardiff. 
IJPDLM

31,9

684
Minh, H. (1991), "International intermodal choices via chance-constrained goal programming", Transportation Research A, Vol. 25A No. 6, pp. 351-62.

Moskowitz, H. (1987), "Decision analysis", in Ravindran, A., Phillips, D.T. and Solberg, J.J. (Eds), Operations Research-Principles and Practices, John Wiley \& Sons, New York, NY, pp. 221-49.

Rosenhead, J. (1989), “Robustness analysis: keeping your options open”, in. Rosenhead, J. (Ed.), Rational Analysis for a Problematic World, John Wiley \& Sons, Chichester, pp. 193-218.

Simon, J.D. (1983), "Public news sources and the monitoring of political risk", in Rogers, J. (Ed.), Global Risk Assessment: Issues, Concept and Applications, Global Risk Assessment Inc., Riverside, California, pp. 99-113.

Tyworth, J.E. and Zeng, A.Z. (1998), "Estimating the effect of carrier transit time performance on logistics costs and service", Transportation Research A, Vol. 32A No. 2, pp. 89-97.

UNCTAD (1994), Multimodal Transport and Trading Opportunities, UNCTAD/SDD/MT/5, UNCTAD, Geneva.

Yan, S., Bernstein, D. and Sheffi, Y. (1995), "Intermodal pricing using network flow techniques", Transportation Research B, Vol. 29B No. 3, pp. 171-80. 
Appendix.

Multimodal

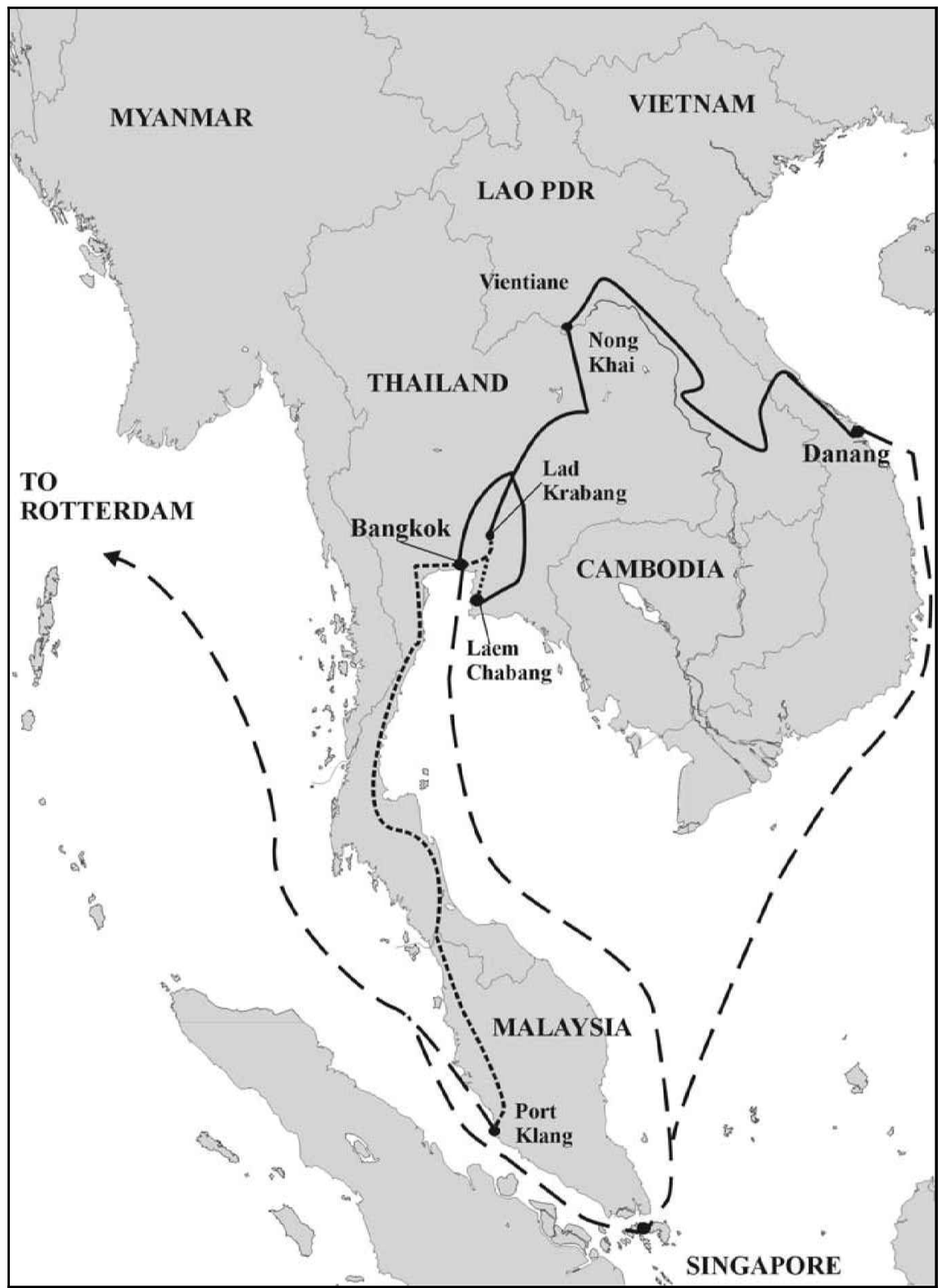

transport

685

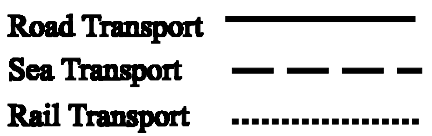

Figure A1. Maps of routing alternatives for lao garment exporters 